\title{
GEOLOGIC MAP OF THE KENNEABAGO LAKE QUADRANGLE, FRANKLIN COUNTY, MAINE
}

\author{
By Eugene L. Boudette
}

\section{INTRODUCTION}

\section{Previous work}

The earliest reconnaissance geologic investigations in this part of Maine were by Jackson (1837, 1839), Holmes and Hitchcock (1861, 1862), Hitchcock and Huntington (1874), and Hitchcock (1877, 1878). Other early studies included the granitic plutons by Dale (1907), the Rangeley Conglomerate by Smith (1923), and the bedrock geology by Keith (1933).

Studies related to mineral occurrences in the region were reported by Pratt and Allen (1949) on agricultural limestone, and by Wing and Dawson (1949) and Wing (1951a,b) on asbestos, serpentinite, and greenstone. Many independent mining companies actively studied base-metal deposits during the period from 1950 to 1968.

Detailed geologic investigation of central-western Maine began in 1948 with a study of the Moose River synclinorium by Boucot (1961, 1969). In 1956, the U.S. Geological Survey began a research program in central-western Maine with an ultimate objective of evaluating the mineral-resource potential of the region. This work included geochemical exploration (Post and Hite, 1964), aeromagnetic mapping (Bromery and Gilbert, 1962; Bromery, Soday, and others, 1963; Bromery, Tyson, and others, 1963; Henderson and others, 1963a,b; Boynton and Gilbert, 1964a,b,c,d; Henderson and Smith, 1964), aeromagnetic applications (Boucot and others, 1964), gravity studies (Kane and Bromery, 1966; Kane and Peterson, 1961; and Kane, 1968), and 1:62,500-scale geologic mapping, including the work described here. Geologic quadrangle mapping is summarized in figure 1. Billings (1956) simultaneously compiled the geology of New Hampshire and described both metamorphic rocks on strike with those in central-western Maine and correlative plutonic rocks. Willard (1958, 1959a,b) first mapped and described the geology of the Kennebago Lake quadrangle as part of a regional study of central-western Maine.

Boucot and others (1964) mapped the distribution and the regional subdivisions by age and lithology of the plutonic and metamorphic rocks. Boucot $(1961,1969)$ also established the stratigraphy of the Silurian and Devonian rocks northeast of the Kennebago Lake quadrangle, partially mapped the distribution of peripheral pre-Silurian units, and identified a regional fault which borders the southeast flank of the Moose River synclinorium and projects on regional strike through the northern part of the Kennebago Lake quadrangle. Albee (1961) recognized at least three major subdivisions within the pre-Silurian rocks of centralwestern Maine and defined the geometry of the Boundary Mountains anticlinorium (Cady, 1960). Albee (1961) suggested that the highly metamorphosed Chain Lakes diamictite and less metamorphosed Jim Pond Formation were stratigraphically correlative with the Ammonoosuc Volcanics of New Hampshire, but Boucot's (1961; see also Ells, 1887) interpretation of the highly metamor- phosed rocks as Early to Middle Proterozoic remains valid and the Jim Pond is older than the Ammonoosuc (see also Boudette, 1982, and Boudette and Boone, 1976).

Silurian rocks older than those of the Moose River synclinorium occur in the quadrangle. A northwest-trending marine onlap during the Silurian was established (U.S. Geological Survey, 1965). Harwood and Berry (1967) determined a Middle Ordovician age for rocks in the Cupsuptic quadrangle (fig. 1) on regional strike with a unit in the southwestern corner of the Kennebago Lake quadrangle. Moench (1969) defined and mapped the Upper Ordovician(?) and Quimby and Greenvale Cove Formations in the Rangeley quadrangle. The Rangeley Formation and Perry Mountain Formations were revised and defined by Osberg and others (1968) in their description of the Kearsarge-central Maine synclinorium. Green and Guidotti (1968) refined the regional geology of the Boundary Mountains anticlinorium and further subdivided and described major pre-Silurian units with the exception of Early to Middle Proterozoic basement rocks of the structure.

Hussey and others (1967) presented the second synthesis of the regional geology of Maine. Osberg and others (1985) have revised and updated this to a third synthesis.

The essential aspects of the tectonostratigraphic synthesis advocated in this report were presented by Boone and others (1970) and Boudette and Boone (1971, 1976, 1984) and Moench and others (1981). Moench and Boudette (1970) and Moench and others (1989) described in detail the stratigraphic relationships within the northwest limb of the Kearsarge-central Maine synclinorium which extends across the Rangeley quadrangle (fig. 1) immediately south of the Kennebago Lake quadrangle. Pankiwskyj (1970) described calcareous rocks in the Stratton quadrangle to the northeast which are equivalent to part of the Rangeley Formation in the Kennebago Lake quadrangle. Boudette (1970) described the pre-Silurian stratigraphic succession in the southern part of the Chain Lakes quadrangle, including units on strike with those in the Kennebago Lake quadrangle and established the presence of the Cambrian and Ordovician ophiolite sequence and of the Early to Middle Proterozoic core of the Boundary Mountains anticlinorium.

Harwood and others (1970) summarized the regional geology of the Boundary Mountains anticlinorium in the vicinity of the Maine-New Hampshire boundary and suggested age assignments of major stratigraphic units which were extensively revised during mapping of the Kennebago Lake quadrangle. Harwood (1970) also summarized field evidence for the Taconian ${ }^{1}$ orogeny in west-central Maine, some of which is observable in the western portion of the Kennebago Lake quadrangle. Boone (1970, 1973)

\footnotetext{
${ }^{1}$ The convention of Poole (1967 p. 20) is adopted herein; therefore, “...Taconian is preferred to Taconic in order to extend the term to orogenies beyond the time limits and style of deformation of the type area in the Taconic Mountains of eastern New York and adjacent states."
} 
described relict sedimentologic structures in the Little Bigelow Mountain quadrangle which have significant bearing upon interpretation of the genesis and deformation of pre-Silurian metamorphic rocks in the Kennebago Lake quadrangle. Moench (1966, $1970 \mathrm{a}, \mathrm{b})$ described a process of cleavage development during diagenesis and concurrent detachment faulting in rocks correlated with those of Late Ordovician(?) and Silurian age in the Kennebago Lake quadrangle.

Other detailed studies have been conducted in the nearby or adjacent Rangeley and Phillips quadrangles (Moench, 1971), the Cupsuptic and Arnold Pond quadrangles (Harwood, 1973), Spencer Lake and Stratton quadrangles (Andrew Griscom, unpub. data; Serra, 1973), and Little Bigelow Mountain quadrangle (Boone, 1973). Details of the geology of the Kennebago Lake quadrangle are given by Boudette (1978). Tectonic synthesis of centralwestern Maine (Boudette, 1982) emphasizing the role of the ophiolite-melange-flysch carapace succession is a helpful introduction to the geologic framework of the region (see also Moench and others, 1989).

\section{Acknowledgments}

Geologists participating in the field studies included D.S. Harwood, H.W. Day, C.W. Thayer, J.A. Colburn, Jeffrey Smith, David Nellis, J.D. Murray, E.S. Grew, Brian Trask, W.B. Thompson, and P.J. Thompson. Steven Goldthwaite and Timothy Targett assisted in field checking. A.J. Boucot (Oregon State University) processed and identified the Silurian fossil collections and furnished ecological data to characterize the sedimentologic environment. W.L. Seymour and J.A. Bratt (Anaconda American Brass, Ltd.) made their regional geologic data available. W.S. Henika (formerly with The Johns-Manville Corporation) helped with portable magnetometer traverses.

The field work was greatly facilitated by the cooperation and help of the following: The Brown Company, E.W. Spaulding Company, The Dead River Company, Viles Timberland Company, Hudson Paper Company, the Kennebago Camp Owners Association, the late Bronson W. Griscom, The Maine Forest Service, and the Maine Warden Service.

\section{REGIONAL GEOLOGIC SETTING}

The Kennebago Lake 15-minute quadrangle extends from the southeastern flank of the Boundary Mountains anticlinorium to the northwestern margin of the Kearsarge-central Maine synclinorium (Lyons and others, 1982), and probably contains the greatest diversity of stratigraphic units in central-western Maine. The preSilurian rock sequences in central-western Maine belong to the Gander zone and the Silurian and Devonian sequences to the "successor basin" tectonic lithofacies categories of Williams (1978).

Two important features in the rocks that underlie the Kennebago Lake quadrangle are (1) a small portion of the Chain Lakes massif, near the northwest corner of the quadrangle, which is a segment of Helikian (Early to Middle Proterozoic) continental crust at least $1,600 \mathrm{Ma}$ in age (Naylor, 1975) that has intrusive Tremadocian(?) or older ophiolite welded to its southeast margin; and (2) a tectonic hinge zone which traverses the medial part of the quadrangle on regional strike and separates intergraded Caradocian and Ashgillian rocks grading into Llandoverian rocks to its southeast from late Llandoverian (C4-C5) and younger rocks deposited on an angular unconformity to its northwest. The proximity of the two features suggests that the massif played a major tectonic role during development of the Taconian unconformity (Boudette, 1982). The principal occurrence of the Chain
Lakes massif is north of the Kennebago Lake quadrangle on the crest of the Boundary Mountains anticlinorium in Maine and Quebec.

Metamorphic rocks younger than the Chain Lakes massif in central-western Maine pass gradually from the supracrustal regime (regional greenschist facies with locally overprinted hornfels) to their infracrustal equivalents (mostly amphibolite facies) from northwest to southeast across the region. Prograde metamorphism in the Chain Lakes massif ranges from the upper amphibolite to granulite facies and was probably a Proterozoic event. The Chain Lakes massif probably was detached from either Europe or Africa after this event. The massif apparently behaved like a buttress throughout Paleozoic time after its arrival in North America. Because of its age, lithology, and tectonic history, the massif is not to be confused with Late Proterozoic and Caradocian rocks in the Oliverian domes of New England.

As shown in figure 2, the layered metamorphic rock successions of the region are assigned to four tectonostratigraphic divisions (Boudette and Boone, 1976; Boudette, 1982): (I) the Chain Lakes massif basement, composed of diamictite, aquagene metavolcanic rocks, and metasedimentary rocks; (II) Tremadocian(?) or older ophiolite (principally pillowed greenstone) and volcanic rock-flysch succession of the Jim Pond Formation, melange of the Hurricane Mountain Formation, and flysch carapace of the Dead River Formation (Boone, 1973); (III) Caradocian to Ashgillian mostly euxinic flysch of an unnamed formation and the Quimby Formation, and euxinic flysch grading up into turbidite and laminated metasandstone of the Greenvale Cove Formation (Moench, 1969); and (IV) Llandoverian to Eifelian molasse-like deposits grading up into cyclic turbidite of the Rangeley and Perry Mountain Formations (Moench and Boudette, 1970; Moench and others, 1989). Sections I and IV are incomplete in the Kennebago Lake quadrangle. The most complete section of division IV rocks occurs south of the quadrangle along the medial part of the Kearsarge-central Maine synclinorium.

The tectonostratigraphic divisions in the quadrangle variously contain three major intrusive suites: (1) the plutonic (or stratigraphically lowermost) components of the ophiolitic Boil Mountain Complex (see also the Boil Mountain ophiolitic complex of Coish and Rogers, 1987), (2) an Emsian(?) calc-alkalic gabbro-dioritegranite suite, and (3) Eifelian to Givetian granite and granodiorite. The complete ophiolite sequence includes the Boil Mountain Complex and the greenstone volcanic member of the Jim Pond Formation (Boudette, 1982).

The boundary between the Chain Lakes massif and the ophiolite is a classic tectonic surface which displays evidence of mild thermal metamorphism and protoclasis. This contact has been described in detail by Boudette (1982), and is interpreted to be the result of emplacement of a hot slab of ophiolite on an obduction surface. The nature of the boundary between divisions II and III is presently an equivocal matter, but is interpreted to be either a tectonic break, such as the base of a stacking-slice gravitydetachment slide, or an unconformity. The boundary between divisions III and IV, as described above, is either gradational or unconformable; this depends upon the relative position of the tectonic hinge zone. The approximate sequence in division II, in ascending order is (1) pillowed greenstone with interlayered metadacite near its top, (2) cherty iron-formation of the Jim Pond Formation, (3) metaquartzwacke and flysch of the Jim Pond Formation, (4) euxinic, proximal-type flysch and acccretionary melange of the Hurricane Mountain Formation, and (5) quartzose and calcareous, distal-type flysch of the Dead River Formation. 


\section{STRATIGRAPHY}

\section{Unnamed rocks of the Chain Lakes massif}

The Chain Lakes massif was named informally by Boudette (1970) for the granofels basement rocks. Rocks that represent the stratigraphically uppermost part of the Chain Lakes massif (YXc) occur along a strike belt about $500 \mathrm{~m}$ wide on the north side of Boil Mountain in the extreme northwest corner of the quadrangle. The Chain Lakes sliver extends into the quadrangle from the west and is abruptly terminated by the Squirtgun fault. The presence of the Chain Lakes in the quadrangle, with ophiolite welded to it, probably is the result of a large-scale detachment on the margin of a trench and its incorporation into a large-scale gravity slide into an accumulating melange in Tremadocian or earlier time.

\section{Jim Pond Formation}

The Jim Pond Formation has been described in detail (Boudette, 1978) and named formally (Boudette, 1982). The Jim Pond occurs in two belts extending along strike in the quadrangle, separated either by the Boil Mountain Complex, allochthonous serpentinite, or the Squirtgun fault. The northern belt (1 to $2 \mathrm{~km}$ wide) lies north of the Squirtgun fault. The 1-to-3.5-m-wide southern belt underlies Cow Ridge, the Barnard Mountains, and Greenbush Mountain, south of the Squirtgun fault.

The Jim Pond Formation is internally complex because of abrupt facies changes both along and across strike. Five informal lithologic members are recognized. In approximate ascending order they are (1) mafic metavolcanic (principally greenstone; O€jg), (2) felsic metavolcanic (O€jk), (3) iron-formation (O€ji), (4) metaquartzwacke (O€jq; mostly a "broken formation; see Boone and Boudette, 1979), and (5) melange (O€jf). Each of the members is variously interrelated gradationally or has been emplaced by gravity sliding. The felsic metavolcanic and iron-formation members occur in place in the northern belt and as slide blocks and rafts of exotic rocks within the melange member. At least one raft of the felsic metavolcanic member occurs within the Hurricane Mountain Formation ( $\mathrm{O} € \mathrm{~h}$ ) south of Barnard Pond. The other members occur in various proportions in both belts of the formation. At least one large slide block nearly $2.5 \mathrm{~km}$ long of pillowed greenstone (O€jgp) occurs within the quartzwacke member of the southern belt on Cow Ridge. Although some internal folding occurs in the quartzwacke and greenstone members of the southern belt, the formation here is as much as $3 \mathrm{~km}$ thick. The Jim Pond in the northern belt is about $1 \mathrm{~km}$ thick.

\section{Hurricane Mountain Formation}

The Hurricane Mountain Formation (O€h) was first described as unit 3 of stratigraphic division II of Boudette and Boone (1976) and recognized by name in 1981 (Boone, 1983, 1985). The formation is named for Hurricane Mountain, located in the southcentral part of the Pierce Pond 15-minute quadrangle in westcentral Maine where good outcrops exist. The formation is no more than 1,500 m thick (actually a tectonic thickness) and represents a composite section which includes Hurricane Mountain, the Brassua Lake lowland to the northeast (Boone, 1983), and Grand Falls of the Dead River to the southwest of Hurricane Mountain.

The lithologies of the Hurricane Mountain Formation in the type area have been described by Boone (1983). Both the lower contact with the Jim Pond Formation and the upper contact with the Dead River Formation can be seen in either the composite section area or at other places along strike. Because the Hurricane
Mountain is a melange with rafts of exotic lithologies up to $200 \mathrm{ft}$ long, the formation has not been subdivided into members (Boone, 1983).

The Hurricane Mountain Formation traverses the quadrangle principally as a belt up to $2.6 \mathrm{~km}$ wide, bounded by the Tim Pond ${ }^{2}$ lowland on the southeast and the southern belt of the Jim Pond Formation on the northwest. Two minor occurrences appear on Eustis Ridge in an anticlinal core south of the Kennebago Lake fault. The Hurricane Mountain is the lower euxinic, flaser-bedded unit of the principal flysch sequence of division II, which combines the Hurricane Mountain and Dead River Formations. This unit is carbonaceous and sulfidic, a melange facies, and is the most easily eroded metasedimentary unit of the quadrangle. The maximum thickness of the Hurricane Mountain Formation in the quadrangle is about $700 \mathrm{~m}$.

\section{Dead River Formation}

The Dead River Formation, named by Boone (1973), succeeds the Hurricane Mountain Formation to the southeast. The Dead River occurs as a belt as much as $4 \mathrm{~km}$ wide across the quadrangle, is nearly as erodable as the Hurricane Mountain Formation, and, together with the Hurricane Mountain Formation, is geomorphologically responsible for the Tim Pond lowland. The Dead River Formation completes the principal pre-Middle Silurian flysch sequence and is subdivided into two informal members. The lowermost member $(O € \mathrm{dp})$ is principally red and green variegated metapelite which grades upward into the upper calcareous metasandstone member $(\mathrm{O} \in \mathrm{dq})$. Well-developed bedding, wellpreserved soft-sediment deformational features, and pinstripe lamination characterize the unit. The top, if present, is concealed by unconformable Silurian rocks. As much as $1.2 \mathrm{~km}$ of the unit may be present in the quadrangle.

\section{Unnamed formation}

Euxinic metapelite and metagraywacke (Osg) occur along the southwestern boundary of the quadrangle in two belts, each about $2 \mathrm{~km}$ across. This unit may be seen to the west surrounding Kamankeag Pond in the Cupsuptic 15-minute quadrangle where the rocks have been dated by fossils (Harwood and Berry, 1967; Harwood, 1973). The name "Dixville Formation" was applied by Green $(1964,1968)$, but much confusion presently exists concerning the application of the name "Dixville", and, until the problem is resolved, no name is adopted herein. The unnamed formation is repeated by folding and as much as $1.6 \mathrm{~km}$ thick in the quadrangle.

\section{Quimby Formation}

The Quimby Formation, named and described by Moench (1969, 1971), occurs in two belts extending along strike in the quadrangle: (1) a northwestern belt, as much as $1.2 \mathrm{~km}$ wide, stretching from the southwestern edge of the quadrangle northeast to Blanchard Ponds with a reappearance south of Eustis Ridge; and (2) a southeastern belt as much as $5.2 \mathrm{~km}$ wide which dominates the entire southeastern corner of the quadrangle and is contiguous with the type section in the Rangeley quadrangle. The Quimby is repeated by folds in both belts and by the Rangeley Lake fault in the southeastern belt. The formation is subdivided

\footnotetext{
${ }^{2}$ Note that Jim Pond and Tim Pond are two different features. Jim Pond is located in the Jim Pond 7.5-minute quadrangle north of the Kennebago Lake quadrangle (fig. 1). Tim Pond is located near the center of the Kennebago Lake quadrangle.
} 
informally into a lower metagraywacke member (Oqg) and an upper metashale member (Oqs). Both members are present in the northwestern belt but only the metashale member is present in the southeastern belt. About $500 \mathrm{~m}$ of Quimby occurs in the northwestern belt and $600 \mathrm{~m}$ in the southeastern belt.

\section{Greenvale Cove Formation}

The Greenvale Cove Formation $(\mathrm{Og})$, named and described by Moench $(1969,1971)$, occurs in belts as much as $600 \mathrm{~m}$ wide parallel to the Quimby Formation, and is similarly repeated by structures. The Greenvale Cove is about $200 \mathrm{~m}$ thick. The upper contact is described by Moench (1969) as gradational with the conformably overlying Rangeley Formation through a $10 \mathrm{~m}$ interval. This same contact zone is but a few meters thick north of Blanchard Ponds, in the gorge of the South Branch Dead River, and along the southern border of the quadrangle.

\section{Rangeley Formation}

The Rangeley Formation (Moench and Boudette, 1970; Moench, 1971) is widely exposed in the central and southern parts of the quadrangle and is the principal formation in a broad, folded gravity-detachment klippe of Silurian rocks (the Kennebago allochthon), which is up to $7 \mathrm{~km}$ wide. All other exposures are autochthonous, either as outliers on older rocks or in fold limbs with the Greenvale Cove and Quimby Formations. The stratigraphy of the Rangeley is complex and relatively thin in the middle part of the Kennebago Lake quadrangle because it transcends the tectonic hinge zone; shoreline-proximal facies are important in that area. Rapid facies changes occur to the southeast where distal, basinward facies and dramatic thickening are seen. The Rangeley is divided into three sequences (fig. 3), each characterized by thickness and facies, for purposes of discussion herein only. From northwest to southeast they are (1) Kennebago Lake, (2) Blanchard Ponds, and (3) type section (in the extreme southeastern corner of the quadrangle). Each of these sequences generally can be characterized by either the presence or thickness of the three principal lithologic parts of the Rangeley Formation, members A, $B$, and $C$ in ascending order. The Kennebago Lake sequence contains none of member $A$. All members increase in thickness to the southeast. Each of these members is, in turn, subdivided into lithologic units on the map. Member $\mathrm{A}$, in ascending order, is subdivided into arkosic metasandstone (Sras) and polymictic metaconglomerate (Srac). Member B (Srb) is not subdivided, but contains both polymictic metaconglomerate and metapelite. Member $C$ is subdivided into orthoquartzite and quartz metaconglomerate (Srcq), metalimestone (Srcl), and metasandstone and metapelite (Src). Member A appears south of the Kennebago Lake fault only in the Blanchard Ponds and type section sequences. A late Llandoverian C4-C5 shell fauna described and dated by A.J. Boucot (1964, written commun.) occurs in member $C$ in the Kennbago Lake and Blanchard Ponds sequences both north and south of the Rangeley Lake fault. About $700 \mathrm{~m}$ of Rangeley Formation, from member $A$ through member $C$, is present in the Kennebago Lake and Blanchard Ponds sequences. Only the lower part of the type-section sequence is present in the quadrangle; the partial section of the Rangeley here is about $1.3 \mathrm{~km}$ thick compared to a thickness of about $3 \mathrm{~km}$ for the complete Rangeley (see also Moench and Boudette, 1987).

\section{Perry Mountain Formation}

Three infolded occurrences of the Perry Mountain Formation (Sp) (Moench and Boudette, 1970; Moench, 1971) are in the
Kennebago allochthon. The Perry Mountain is the youngest metamorphic unit mapped in the quadrangle; the top is not exposed in the quadrangle. As much as $450 \mathrm{~m}$ of the Perry Mountain Formation may be present.

\section{Environments of deposition}

Each of the major tectonostratigraphic divisions can be described in terms of its environment of deposition. Precambrian division I rocks represent shallow-marine basin environments of deposition. Upper Cambrian and Lower Ordovician rocks of division II and most of the Middle and Upper Ordovician rocks of division III rocks accumulated, possibly serially, in a depositional prism within a eugeosyncline. The latest Ordovician division III rocks and all Lower Silurian to Lower Devonian division IV rocks accumulated in environments resulting from a rapid change in depositional regime from eugeosynclinal to shoreline and marine trough, such as would occur between microplates or in an intraplate furrow.

Division I rocks. - The rocks of the Chain Lakes massif are an example of a worldwide problem in determining the origin of Precambrian diamictite massifs. All the massifs apparently require a unique combination of provenance and a process of deposition that has not been repeated since Precambrian time. The Chain Lakes massif rocks, both within and north of the quadrangle, are composed of aquagene volcanic rocks of local derivation that both mixed and interlayered with clastic material derived from a subjacent crystalline highland upon which a saprolitic regolith had developed. Those volcanic rocks and sediments were deposited in a relatively shallow marine basin or along a passive continental margin. Internal facies have been proposed to be of impact origin (Boudette and Boone, 1982; Moench and others, 1989).

Division II rocks. - Pillow structure in greenstone, sorting, and bedding thicknesses of the clastic rocks, including those of volcanic tephrite and epiclastic origin, indicate that the Jim Pond Formation is an aquagene volcanic sequence which accumulated in situ, probably in a deep ocean-floor environment at the margin of a trench. The general structure of the greenstone member on Greenbush Mountain suggests a tilted relict shield volcano buried under the metaquartzwacke member. Much of the clastic material in the metaquartzwacke and melange members could be of pelagic origin. Although emergent parts of the ophiolite complex could account for this contribution (Boudette, 1970), the abundance and volume of quartz in the metaquartzwacke member suggests a more remote provenance than the ophiolite. The cherty iron-formation member apparently accumulated in quiet, protected basins in proximity to rocks of the felsic metavolcanic member. The probable sources of the iron and excess silica were active exhalative volcanic centers locally enriched in metals.

The Hurricane Mountain Formation represents deposition in a trench environment and shares many characteristics with the melange unit of the Jim Pond Formation. Uppermost parts of the Jim Pond (especially the melange) and the Hurricane Mountain Formation are described in detail by Boone and Boudette (1989) and assigned to an accretionary wedge, probably in a forearc trench during transpressive subduction. The Dead River Formation is characterized by distinctive, well-developed sorting and pinstripe lamination. This indicates deposition in a low-energy yet welloxygenated environment typical of a lower rise or abyssal plain where the sediments were repeatedly reworked by bottom currents.

Though superposition is at least locally documented-Jim Pond to Hurricane Mountain to Dead River-much of the deposition within these formations could be coeval and have shared the same 
provenance. The present configuration of the formations of division II could be the result of tectonic juxtaposition of the sediments either while they were wet or during diagenesis. Such pre-orogenic tectonic reassemblage of sedimentary prisms could also explain the juxtaposition of division II and III rocks within the quadrangle.

Division III rocks. - The rocks of the unnamed formation and Quimby Formation are interpreted to have been deposited in an environment provided by that of a well-nourished back-arc, extensional basin. The basin environment would have provided the strong signature of bimodal volcanic provenance that the rocks bear as well as a relatively voluminous, continuous source of clastic and volcanic material. The unnamed formation grades conformably into the Quimby Formation with a shift mainly from graywacke to shale. This shift represents a change in the depositional environment by a volume depletion of the clastic source (Moench, 1969). Both formations are classic flysch probably deposited in a deep anoxic furrow in the same manner as the Hurricane Mountain Formation, but apparently not in a trench. The division III flysch displays more well-developed bedding than the Hurricane Mountain Formation. Although the division III flysch contains conglomerate, the melange and flaser bedding are absent in contrast to the rusty flysch of division II.

The Greenvale Cove Formation represents a rapid shift in the sedimentologic regime. An environment where euxinic flysch was deposited since Caradocian time was abruptly terminated, probably as a highland rose to the northwest. The Greenvale Cove contains clastic material that is more mature and well sorted than that of the Quimby Formation. These sediments were deposited in a rather high-energy marine environment, not far from the shoreline (Moench, 1969) under well-oxygenated conditions, probably as a contourite in which bottom currents constantly interrupted sedimentation to produce both parallel and cross-laminations. The Greenvale Cove Formation probably represents a short interval before the arrival of the coarse clastic and mature quartzose sediments of the Rangeley Formation.

Division $I V$ rocks. - Rocks of members A, B, and the lower unit of member $C$ of the Rangeley Formation, as seen in the Kennebago Lake and Blanchard Ponds sequences indicate deposition in shallow-marine and estuarine environments. The Rangeley Formation exhibited in the type-section sequence is characterized by fluxoturbidite rocks which indicate deposition in deeper water. With deeper water in member $\mathrm{C}$ time, limestone of the Kennebago Lake and Blanchard Ponds sequences was deposited. As the water deepened further in late member $C$ and Perry Mountain time, a great volume of cyclically bedded, aluminous turbidite was deposited. The cyclic turbidites are poorly sorted compared to the flysch of pre-Greenvale Cove time, and are relatively free from the effects of extensive reworking by bottom currents.

The Rangeley Formation thickens from northwest to southeast across the quadrangle and continues to do so beyond the quadrangle border. This thickening is best shown by members $A$ and $B$ as they pass from shoreline to deeper water facies. A lower metasandstone unit appears in member $A$ in the southeast which is not found in the Blanchard Ponds sequence. In the Kennebago Lake quadrangle, Rangeley member B contains a lower conglomerate in the southwestern part of Kennebago Lake sequence; in the Rangeley 15-minute quadrangle, this conglomerate is seen in the type-section sequence. Metalimestone, vitreous orthoquartzite, and quartz conglomerate of Rangeley member $\mathrm{C}$ in the Kennebago Lake and Blanchard Ponds sequences do not persist in the type-section sequence to the southeast (fig. 3). The vitreous orthoquartzite and quartz conglomerate are unique to the Kenne- bago Lake sequence. They are seen as a very thin unit within the lowermost unit of member $\mathrm{C}$ and indicate beach, offshore bar, and associated aeolian environments. This thin unit appears to mark the strandline in the tectonic hinge zone where a static shoreline position existed during its deposition.

Member $\mathrm{B}$ is the first unit transgressive over the tectonic hinge zone above the unconformity. Member $\mathrm{B}$ apparently represents tidal-flat, estuarine, and lagoonal sediments deposited shoreward from the beach sediments of member $C$. The pelites of member $B$ are especially aluminous and probably were derived from a deep saprolite terrane which formed on the emergent parts of the Vermont-Quebec geanticline (Cady, 1967). This contribution of aluminous material, which is voluminous in the Kearsarge-central Maine synclinorium (Lyons and others, 1982) was nearly continuous well into Emsian time.

During deposition of the Perry Mountain Formation sediments, turbidite sedimentation was interrupted at least once by the emplacement of quartz-latite sheets. These sheets are conformable to the Perry Mountain Formation and could be either aquagene volcanics or shallow intrusives.

The Hurricane Mountain, unnamed formation, and Quimby Formation are all euxinic units characterized by abundant sulfide and carbon content. Although these formations resemble one another and have much in common, especially with respect to provenance, each has distinctive bedding features which suggest different sedimentary regimes.

Turbidity currents probably were the principal mechanism by which most of the clastic materials were delivered for the rocks of divisions II and III. Thereafter, bottom reworking by traction currents occurred; the degree of resorting in beds is a general indication of the intensity of that reworking. The sedimentary provenance of the Hurricane Mountain Formation, Dead River Formation, unnamed formation, and Quimby Formation, compared to the Jim Pond Formation, probably was multiple and involved simultaneous contributions from both nearby aquagene volcanic sources and more distal crystalline uplands.

The gradation of marine-margin and high-shelf facies to the lower shelf turbidites of division IV is consistent with an environment created by a combination of a shoreline transgressing to the northwest while an intraplate trough of extensional origin widened and deepened to the southeast on a continent. The beds of the cyclic turbidites are better graded than those of the classic flysch of division II and III. The cyclic rocks generally are distinguished from the classic flysch by good (slow) grading and depositional features such as flame structure and cross lamination; euxinic facies are subordinate.

\section{Age and correlation of stratigraphic units}

Probable volcanogenic zircons from a felsic unit of the Chain Lakes massif north of the quadrangle yield a U-Pb age of about 1.6 $\mathrm{Ga}$ (Naylor and others, 1973; Naylor, 1975). The protolith of the Chain Lakes massif in the Kennebago Lake quadrangle is uncertain, but is either an aquagene volcanic rock or an arkosic sandstone. The Chain Lakes massif has no nearby regional counterparts but is lithologically similar to other diamictites in the Appalachians (Boudette and Boone, 1976). Part of the Arnold River Formation of Marleau (1958, 1968), which he thought was of Paleozoic age, is coextensive with rocks of the Chain Lakes massif.

Rocks of division II are equivalent to the undivided Cambrian and Ordovician rocks of Boucot (1961, p. $182 ; 1969$, p. 55-58) to the northeast. These same rocks extend around the southwest- 
plunging nose of the Boundary Mountains anticlinorium and continue along a regional strike southwest into New Hampshire. The Dead River is coextensive with, and equivalent to, the Albee Formation (Green, 1968; Harwood, 1973) and the Aziscohos Formation of Green (1968). This correlation introduces a disparity of age because the Albee and Aziscohos are arbitrarily assigned a Middle Ordovician age. Harwood and Berry (1967; Harwood, 1973) extrapolated the name "Dixville Formation" of Green (1968) to the unnamed formation of Caradocian age, believing that there was a correlation of these rocks across regional strike based upon a supposed equivalence of euxinic flysch. The Dixville Formation is essentially equivalent to the Jim Pond and Hurricane Mountain Formations. On this basis alone, the Jim Pond was called the Magolloway member and the Hurricane Mountain Formation was the sulfidic, carbonaceous Dixie Brook Member of the Dixville Formation of Green (1968). The logic of this correlation was based upon equating the unnamed formation of Caradocian age with fossil-bearing Middle Ordovician rocks in the Brassua Lake quadrangle (Neuman, 1968), some $100 \mathrm{~km}$ to the northeast. To do this, an assumption was made that the Brassua Lake fossils effectively dated the broad belt of rocks herein assigned to division II as also Middle Ordovician. However, Post (U.S. Geological Survey, 1961) and Neuman (1968) clearly distinguished the dated Middle Ordovician rocks of Brassua Lake from the undated but much older rocks along strike with division II. The "original" Dixville of Green (1964) possibly may be of Caradocian age and equivalent to the unnamed formation, but the Jim Pond and Hurricane Mountain Formations almost certainly are not, especially because of the their contrasting lithologic and sedimentologic styles which reflect contrasting depositional regimes. This stratigraphic controversy cannot be resolved completely (Boudette and Boone, 1976) until a clearer picture exists of the "Dixville Formation" (see Moench and Pankiwskyj, 1988).

The metaquartzwacke member of the Jim Pond is most likely equivalent to the Arnold River Formation of Marleau (1968) in its type section on the nose of the Boundary Mountains anticlinorium, about $10 \mathrm{~km}$ northwest of the Kennebago Lake quadrangle.

The ages of division II rocks, the unnamed formation, and the Quimby Formation and Greenvale Cove Formation (of division III) is based primarily on stratigraphic superposition determined by recognition of tops of beds using sedimentary structures and pillows in basalt. Rocks correlative with the Dead River Formation are intruded by the Adamstown granite near the Maine-New Hampshire State boundary. This granite tentatively correlates with the Attean pluton (Albee and Boudette, 1972) by virtue of its texture, mode, and alteration habit. Thus, the Dead River has an implicit minimum age between 455 to $451 \mathrm{Ma}$. (Lyons and others, 1983). G.M. Boone (1979, oral commun.) believes there is evidence in central Maine that the Dead River is overlain unconformably by rocks of Arenigian age. Thus a Tremadocian(?) age or older is tentatively adopted here for the rocks of division II. The intergradational Quimby Formation and Greenvale Cove Formation are contained in a time zone bridged by the fossil-dated late Llandoverian Rangeley member $\mathrm{C}$ and the Caradocian unnamed formation. The Greenvale Cove Formation is conformably below and grades up into Ranglely member A, and the Quimby Formation is conformably above and grades down into the unnamed formation. Thus the Quimby is assigned a late Caradocian(?) to Ashgillian(?) age here consistent with the earlier assignment of Moench (1969, p. L14-L16). The Greenvale Cove and Rangeley members $A$ and $B$, gradational below member $C$, are arbitrarily assigned an early and middle Llandoverian age.
The only known fossils in the Kennebago Lake quadrangle are within member $\mathrm{C}$ of the Rangeley Formation; these are a diagnostic late Llandoverian C4-C5 shell fauna (brachiopods and gastropods) (Moench and Boudette, 1970; Boudette, 1978). Within 2 $\mathrm{km}$ to the west of the quadrangle, Caradocian graptolites occur in rocks coextensive with those of the unnamed formation.

The Perry Mountain Formation, which gradationally overlies the Rangeley, is arbitrarily assigned a Llandoverian to Wenlockian(?) age consistent with the previous assignment by Moench and Boudette (1970).

The Quimby, Greenvale Cove, and Perry Mountain Formations have no close regional counterparts, but the Quimby (along with the unnamed formation) could be equivalent to euxinic rocks of the Ammonoosuc domes of central New England. The Rangeley, especially members $\mathrm{B}$ and $\mathrm{C}$, is equivalent, at least in part, to the Clough and Fitch Formations of New Hampshire. Polymictic conglomerate equivalent in age to that of the Ranglely is found throughout the northern Appalachians.

\section{INTRUSIVE IGNEOUS ROCKS}

\section{Rocks of the Boil Mountain Complex and allochthonous serpentinite}

The Boil Mountain Complex ophiolitic sequence is subdivided into an intrusive suite and a volcanic suite, and both are described in detail and named by Boudette $(1978,1982)$. Coish and Rogers (1987) advocate the use of a more inclusive name, "Boil Mountain ophiolitic complex", to also include juxtaposed metasedimentary rocks. The most prominent body of the Boil Mountain Complex in the quadrangle is within the slide block, in association with the Chain Lakes massif, that underlies Boil Mountain. A small sliver of the Boil Mountain Complex, which also may be a slide block, occurs in the extreme northeastern corner of the quadrangle. Much of the Boil Mountain Complex is autochthonous and occurs mainly north of the quadrangle in a belt which extends into the quadrangle along the western part of the northern border.

Three lithologic facies of the Boil Mountain Complex are recognized: (1) serpentinite (O€bs), (2) gabbro-epidioriteautobreccia-pyroxenite $(\mathrm{O} € \mathrm{bg}$ ), and (3) tonalite (also called trondhjemite or calcic plagiogranite) ( $\mathrm{O} € \mathrm{bt}$ ). The tonalite (3) may or may not be part of the ophiolite, but the interpretation is made herein that it represents the frozen magma chambers which contributed the felsic volcanics of the ophiolite complex. A combination of consanguinous geochemistry and observed gradations between tonalite and felsic volcanics support this interpretation. The distribution of the three facies is unequal within the three occurrences in the quadrangle. To some extent, the facies, particularly (1) and (2) are mixed; thus, the subdivision of (1) and (2) is only general and reflects the dominant rock type in each.

The northeastern part of the Boil Mountain Complex has a stratigraphy wherein the rocks are part of an upright sequence as much as $1.6 \mathrm{~km}$ thick facing southeast. They are relatively enriched in magnesium at their base along the northwestern margin. This lower zone is marked by the occurrence of antigorite, serpentinite (altered harzburgite and dunite) and websterite. The magnesiumrich rocks generally are overlain by massive epidiorite autobreccia (epidiorite and subordinate tonalite), calcic plagiogranite, and minor clinopyroxenite. Greenstone septa (or possibly dikes) are common in the plagiogranite facies. Repetition of lithologies is common near the base, where distinctive igneous layering also is seen. 
The southeastern contact of the Boil Mountain Complex, probably its stratigraphic top, is mostly dominated by a relatively thick layer of tonalite which thins and passes stratigraphically downward to the west. This is the only known place where the rocks of the Boil Mountain Complex and the greenstone of the Jim Pond Formation are in undisturbed contact, but this contact is not well exposed. One series of outcrops shows transition from epidiorite into greenstone, possibly with some repetition of units, in a zone as much as $150 \mathrm{~m}$ across.

Extreme tectonism and metamorphism remobilized segments of the serpentinite of the autochthonous part of the Boil Mountain Complex, mostly north of the quadrangle, to produce clinochrysotile-bearing diapiric (allochthonous) serpentinite. The largest of these diapiric bodies in the quadrangle is about $400 \mathrm{~m}$ across and $5 \mathrm{~km}$ long and is found along the Squirtgun fault. Another prominent body occurs along the North Branch Dead River, shown in the extreme northeastern corner of the quadrangle. Others are distributed throughout the Jim Pond Formation, mostly along subsidiary faults; many more probably exist than are mapped.

\section{Flagstaff Lake pluton, Elephants Head pluton, and unnamed mafic rocks}

Differentiated intrusive rocks characterized by their gabbroic component account for about 25 percent of the rocks in the quadrangle. They have been divided into three major groups: (1) the Flagstaff Lake pluton (the Flagstaff Lake igneous complex of Boone, 1973), (2) the Elephants Head pluton, and (3) a sill and dike swarm in the middle part of the quadrangle. In addition, altered aphanitic mafic dikes less than $1 \mathrm{~m}$ thick (not mapped separately), which intrude the Dead River Formation in abundance, may also correlate with the gabbroic Flagstaff Lake and Elephants Head rocks because of their similar composition.

The sill and dike swarm possibly is the precursor of the larger plutons. The most notable rocks of this group are found in sheets as thick as $15 \mathrm{~m}$ in rocks within the Kennebago allochthon, on the footwall of the Kennebago Lake and Lutton Brook faults, and in nearby rocks. Three unusually large occurrences of these rocks within the Dead River Formation are mapped separately in the western part of the Dead River outcrop belt. All of these occurrences, such as the one at the northwestern end of Kennebago Lake, could have been emplaced along a surface that could be the infolded remnants of the Kennebago Lake fault. One of the significant characteristics of these rocks, seen in the sills of the Kennebago allochthon, is their deformation by slip cleavage, which also deforms slaty cleavage in the Silurian host rocks. The sills behaved as part of the layered stratigraphy and were folded and faulted with the layered rocks. Sills in the north-central part of the quadrangle can be traced into the Flagstaff Lake pluton.

The Elephants Head pluton has been described in detail by Boudette (1978) and was named for Elephants Head on Black Mountain. The summits, upper slopes, and crest lines of Black Mountain, the southwestern part of Sawyer Hill Ridge, and a narrow fault sliver northwest of Norton Brook are underlain by these rocks. All of these rocks appear to be emplaced generally conformably within the Hurricane Mountain Formation and comprise a belt up to $900 \mathrm{~m}$ wide and $6 \mathrm{~km}$ long in the largest occurrence. The Elephants Head pluton is subdivided into a dominant gabbroic facies and a felsic facies. The felsic rocks intrude gabbro on Sawyer Hill Ridge and are therefore younger.

The Flagstaff Lake pluton is a major structure which trends along the regional strike $60 \mathrm{~km}$ from its southwestern terminus in the
Pierce Pond and Little Bigelow Mountain quadrangles. A belt of Flagstaff Lake pluton $25 \mathrm{~km}$ long and as much as $17 \mathrm{~km}$ wide occurs in the Kennebago Lake quadrangle. Four lithologic facies are mapped: (1) norite (Dn) (known only in the southwest part of the quadrangle), (2) gabbro-troctolite (Dga), (3) epidiorite (Dd), and (4) garnet granofels-migmatite (Dgf) (a roof-zone facies). Epidiorite crosscuts granofels in one known instance and is apparently younger. One small zone of the granofels-migmatite, too small to show on the map, occurs at the southeastern contact of the Flagstaff Lake pluton with the Greenvale Cove Formation at the eastern border of the quadrangle on the ridge south of Green Farm. Saprolite, a remnant of a deep regolith that mantled the rocks before the Pleistocene, is developed on the gabbroic rocks of the pluton.

\section{Redington pluton and Seven Ponds pluton}

The extreme southeastern and northwestern corners of the quadrangle are underlain by granite and granodiorite $(\mathrm{Dg})$, respectively, but not in contact. The southeastern rocks are part of the Redington pluton, named and described by Moench (1971). The Redington appears to be intruded semiconformably into member $\mathrm{B}$ of the Rangeley Formation with a sharp, vertical- to southdipping contact. The granodiorite in the northwest corner of the quadrangle is part of the Spider Lake Granite first described and named by Marleau (1957, 1968) in Quebec. Harwood (1973) later called these same rocks in Maine the "Seven Ponds pluton", a name which may ultimately prevail (see Moench and others, 1989, p. 28-38). None of the Seven Ponds rocks, though present, are exposed in the quadrangle. Their occurence is projected from nearby control west of the quadrangle by Harwood (1973) and exposures within $0.5 \mathrm{~km}$ northeast of the quadrangle. Where seen to the northeast, the Seven Ponds pluton appears to be in sharp, conformable contact with older rocks.

\section{Lamprophyre dikes}

One lamprophyre dike ( $\mathrm{kI}$ ), which strikes northwest, is mapped within the Redington pluton. Two others occur in the regional grain, one within the Quimby Formation in the South Branch Dead River, and the other in the Jim Pond Formation in Alder Stream. Many more may be present but are not observable because these rocks are easily eroded. All of these dikes postdate regional deformation and metamorphism.

\section{Emplacement and petrogenesis of intrusive rocks}

The combination of stratiform geometry, layered habit, and magnesium-enriched base of the Boil Mountain Complex suggests that it was derived from a parent magma by crystal settling. The differentiation suite is interpreted to be peridotite-gabbroepidiorite-plagiogranite. The distinctive autobreccia facies appears to have formed cyclically by some process of breakage internal to the Boil Mountain Complex. This process probably was related to ophiolite emplacement. A process of explosive release is likely such as would occur during unroofing or initiation of tectonic transport. The process is consistent with conditions at the ophiolite source environment of magmatic crystallization in either isothermal or polythermal decreasing $P_{\text {load }}$ conditons.

The spatial relation of diapiric (allochthonous) serpentinite to faults within the Jim Pond Formation provides at least three possibilities for the generation of these rock bodies: (1) they were broken and carried away from autochthonous serpentinite bodies by the faults; (2) they were originally exotic slide blocks of 
serpentinite rafted into the Jim Pond Formation and later tectonically smeared by the faults; or (3) they were small ultramafic intrusions directly emplaced within the Jim Pond Formation, creating zones of weakness which localized faults. Some combination of (1) and (2) probably explains the unique correlation with the Jim Pond Formation.

Chilled margins, baked host rock, hypabyssal textures, alteration, and synkinematic deformation all suggest that the Emsian(?) sill and dike rocks were probably comagmatic precursors of the Flagstaff Lake and Elephants Head plutons. Roof pendants, roofreaction facies, and development of pronounced contact aureoles implies that the plutons are barely exposed at the present level of crustal erosion. The development of the distinctive granofelsmigmatite facies of the Flagstaff Lake pluton appears to be the result of partial melting of unstable protoliths which, at least in part, are uppermost Quimby Formation and lowermost Greenvale Cove Formation. The trace of the tectonic hinge zone and the trend of the Flagstaff Lake pluton, which appears to form southeast-dipping stratiform sheets, are closely parallel. The relationship may be more than a coincidence; during emplacement, the pluton may have exploited a regional zone of weakness, related to the hinge zone.

The Redington pluton may be best explained as a welt on a larger concealed stratiform sheet (Moench and Zartman, 1976; R.H. Moench, 1978, written commun.). The Seven Ponds pluton could have a similar origin, but observations north of the quadrangle indicate that it is a conformable antiformal sheet rooted to the northwest and pinching out to the southeast.

Alkalic nature, emplacement in joints of brittlely deformed rocks, chilled margins, and amygdular texture of lamprophyre dikes all suggest anorogenic emplacement at a high crustal level. These dikes probably relate to conditions of extension in the orogen such as might have accompanied aulocogenesis during break-up. This event may have been the segmentation of Pangea.

\section{Age and correlation of intrusive rocks}

Isotopic ages are not presently available for any intrusive rocks in the quadrangle. Tonalite of the Boil Mountain Complex, which is younger than the Chain Lakes masiff, has been isotopically dated at $515 \mathrm{Ma}$ (Eisenberg, 1981). The Boil Mountain Complex is older than the Attean pluton which intrudes directly correlative rocks northeast of the quadrangle. The age of cold diapirism of the allochthonous serpentinite could range up to Acadian or younger, when faults were active. The Boil Mountain Complex correlates with a soapstone belt in the Connecticut River Valley (Lyons and others, 1982) and with ultramafic rocks on strike across Maine to the northeast in an ophiolitic melange zone (Boudette, 1982; Boone and Boudette, 1989).

The maximum age of the sills of the Kennebago allochthon and rocks of the Flagstaff Lake pluton is fixed by the paleontologically dated contact aureole of member $\mathrm{C}$ of the Rangeley Formation. Gabbro of the Flagstaff Lake pluton correlates with the Moxie pluton to the northeast, isotopically dated at 386-393 Ma (Espenshade and Boudette, 1967). Rocks of the Elephants Head pluton probably correlate with similar rocks mapped by Harwood (1973) as granodiorite near Little Kennebago Lake in the Cupsuptic 15-minute quadrangle to which he arbitrarily assigned a Middle to Late Ordovician age. This latter age is not accepted herein because textural and modal data suggest that the rocks of the Elephants Head pluton and the granodiorite at Little Kennebago Lake are more likely related to the rocks of the Flagstaff Lake pluton and are therefore also Emsian(?).
Rocks of the Redington pluton correlate with the similar Lexington batholith and Mooselookmeguntic pluton, both in the same strike belt, which are isotopically dated $380 \mathrm{Ma}$ (Moench and Zartman, 1976) and $395 \mathrm{Ma}$ (Naylor, 1975), respectively. All of these rocks are part of an extensive central New England belt of batholiths which was emplaced synkinematically during the Acadian orogeny.

Lamprophyre dikes are widespread, abundant and, in New England, traditionally assigned to the Triassic; the convention is preserved here. These dikes possibly indicate crustal extension at the time of Pangean dismemberment, which occurred during or close to Triassic time.

\section{STRUCTURE}

\section{Faults}

Two types of faults are recognized in the quadrangle: (1) early, pre-orogenic gravity-detachment structures (down-to-basin faults of Moench, 1970a,b; 1973) which mostly strike parallel to the regional grain, and (2) late dislocations by brittle deformation with variable orientations. The principal detachment faults are the Kennebago Lake fault, the Lutton Brook fault, and the Rangeley Lake fault. The structure of the Rangeley Lake fault could be complicated, however, by later brittle movement. Large exotic blocks in the Jim Pond Formation and Hurricane Mountain Formation also are shown bounded by faults of gravitydetachment origin, although the mechanism of slip differs from that of the larger structures. The most important late faults are strike faults-the Squirtgun fault and the Fansangah Gorge fault. Brittle deformation faults which break cross strke, such as the Spotted Mountain fault, cause local truncation of rock units, and are associated with diapiric serpentinite-soapstone bodies in the Jim Pond Formation. Aside from truncations and smeared serpentinite, the faults are recognized by a combination of other criteria such as slickensides, cataclastic deformation, silicification, and topographic lineaments.

The Kennebago Lake and Lutton Brook faults combine to define the Kennebago allochthon which was later deformed by folding and late faulting. The Rangeley Lake fault is an extension of a structure mapped and described by Moench $(1971,1973)$ which continues several kilometers to the southwest, but to an unknown distance to the northeast. Minor structure and the geometry of displacement along the Rangeley fault in the northeast suggest that the fault may have caused localized late brittle deformation along a reverse fault, possibly during intrusion of the Redington pluton, which appears to have shoved the rocks northwestward.

The Squirtgun fault is an uninterrupted mappable structure that extends more than $90 \mathrm{~km}$ on strike from the northwestern corner of the quadrangle east to Moosehead Lake. In this quadrangle, sections of the Squirtgun fault are a thrust fault dipping $45^{\circ}$ or less to the southeast. To the northeast, beyond the quadrangle, however, sections of the fault are vertical and, by the evidence of minor structures, are dominated by right-lateral rotational mechanics. The Squirtgun fault is, therefore, interpreted to be complex and to have developed in successive stages of thrust, segmentation, rotation, and strike-slip motion. This fault could be a model for other faults of central-western Maine and proabaly is equivalent to the Ammonoosuc fault of New Hampshire.

\section{Folds}

The Tim Pond-Dead River syncline is the only fold of regional scale mapped in the quadrangle. The syncline trends from Kenne 
bago Lake northeast to Eustis Ridge in this quadrangle, but its entire length is more than $40 \mathrm{~km}$. This structure is defined mostly by the Hurricane Mountain and Dead River Formations, but is interpreted to explain an inlier of members $B$ and $C$ of the Rangeley Formation on the north flank of Eustis Ridge and on the Lookout Hills. A major syncline containing the Quimby, Greenvale Cove, and Rangeley Formations, and its complementary anticline to the north, is inferred north of Spotted Mountain. Tightly appressed minor folds appear in nearly all the layered units in this quadrangle except within the Kennebago allochthon southwest of the Lutton Brook fault. In the Kennebago allochthon, the fold style is more open which gives the allochthon the general character of a rumpled sheet. One sharp recumbent flexure on East Kennebago Mountain is associated with a small reverse fault. Northeast of the Lutton Brook fault, the Kennebago allochthon itself becomes in part a tightly appressed syncline. Folds in the rocks the age of member $A$ of the Rangeley Formation and older were, if not isoclinal by the end of the early Caledonian (Taconian and older) orogeny, probably appressed and, in some cases, broken during the late Caledonian (Acadian) orogeny. No particular folding interference pattern resulting from multiple orogenic tectonics is evident. The orogenic stress fields throughout the Caledonian orogeny were of nearly the same orientation.

\section{Minor structural features}

Minor folds, lineations, and probably cleavage (of both orogenic and gravity-tectonic origin) characterize the rocks of the quadrangle. In addition, small-scale sedimentary structures are preserved in almost all of the clastic metamorphic rocks. Describing which minor folds are of orogenic origin and which are of gravity-tectonic origin is not always possible, particularly in the pre-Silurian clastic metamorphic rocks. Structural analysis by stereographic projection is of limited value in the study of these rocks. Interference folding is small in scale; although it is present, especially in the Dead River Formation, it is not conclusively indicative of multiple orogeny. Older rocks were subjected to the Taconian (early Caledonian) orogeny, and all rocks were deformed during the Acadian, late Caledonian, and (possibly to some degree) the Hercynian orogenies. Some minor folds are related to intrusive crowding and late faults. Hinges of minor folds are rarely developed in the pre-Middle Ordovician rocks, and those few are almost always steeply plunging. In most exposures of these rocks, the tops of bedding indicate that they were isoclinally folded on a small scale and the hinges were broken. Both early- and late-forming cleavage are distinguished on the map.

The early cleavage possibly formed, in part, by dewatering or pressure solution. Early cleavage shown on the map is either (1) gneissic foliation in migmatite, (2) transverse (slaty and fracture) cleavage (equivalent to axial-plane flow), (3) bedding-plane cleavage, or (4) schistosity. Gneissic foliation in rocks of the Chain Lakes massif is nearly everywhere parallel to bedding and is related to original lithification and metamorphic prograding. Early cleavage formed in the pre-Silurian rocks of the quadrangle probably during the Taconian orogeny and in younger rocks during the Acadian orogeny. Excellent kinky refracted cleavage is present in some of member $\mathrm{C}$ of the Rangeley Formation of the Kennebago allochthon, especially the nearly flat lying rocks; sigmoidal refracted cleavage is present in the Perry Mountain Formation. Refolded cleavage and bedding can be seen along late faults and adjacent to intrusive rocks. Transverse cleavage cannot be demonstrated everywhere to be of the axial-plane type, and in some places it is clearly not axial-planar to the nearest mapped folds. Early fracture (transverse) cleavage is developed almost exclusively in the quartzose metasandstone bottoms of well-sorted, thick sand-pelite beds in member $\mathrm{C}$ of the Rangeley Formation and always passes up (with a refraction kink) into metapelite tops.

Late-forming cleavage includes fracture cleavage, slip cleavage, kink bands, and some transposition banding. In some places, the late cleavage is either parallel to nearby faults or may be related to intrusive crowding. Every gradation between kink bands and slip cleavage, with concurrent rotation in some places, was observed, especially in pelitic rocks. Thus, distinction between them is artificial. Fracture cleavage spacing varies from closely spaced (as in slaty cleavage) to as much as $2 \mathrm{~cm}$. The term "spaced cleavage" is sometimes used for the latter type. Fracture cleavage spacing "grades" into parallel jointing in some outcrops. Kink-band development is spatially related to faults. Early bedding-cleavage lineations are present in Silurian rocks and indicate major fold plunges, but none of these are mapped. Late lineations produced by mineral streaking (slip strain?) is mapped, however, and almost all of these are proximal to late faults.

Structures of depositional origin are found in nearly all the metamorphic rocks. Pillows in the Jim Pond Formation were described previously. Flute casts are found in the Dead River Formation and may be misinterpreted as tectonic lineation. Load casts, convolute structure, flame structure, and sand-mud interflow (sand dikes) are common in the Silurian rocks. Several sand dikes were seen in the Dead River Formation.

\section{REFERENCES CITED}

Albee, A.L., 1961, Boundary Mountain anticlinorium, west-central Maine and northern New Hampshire, in Short papers in the geologic and hydrologic sciences, Geological Survey Research, 1961: U.S. Geological Survey Professional Paper 424-C, p. C51-C54.

Albee, A.L., and Boudette, E.L., 1972, Geology of the Attean quadrangle, Somerset County, Maine, with a section on Geologic interpretation of the aeromagnetic map by J.W. Allingham and A.L. Albee: U.S. Geological Survey Bulletin $1297,110 \mathrm{p}$.

Billings, M.P., 1956, Bedrock geology, pt. 2 of The geology of New Hampshire: Concord, N.H., New Hampshire State Planning and Development Commission, 203 p.

Boone, G.M., 1970, Pre-Silurian flysch relict structures in cordierite-K-feldspar granofelses, Long Falls of Dead River, Somerset County, western Maine, in New England Intercollegiate Geological Conference, 62d Annual Meeting, Rangeley, Me., Oct. 2-4, 1970, Guidebook for trips in the Rangeley Lakes-Dead River basin region, western Maine: [Syracuse, N.Y., Syracuse University, Department of Geology], Trip B-1, p. 1-16. (Edited by G.M. Boone.)

1973, Metamorphic stratigraphy, petrology, and structural geology of the Little Bigelow Mountain map area, western Maine: Maine Geological Survey Bulletin 24, 109 p., scale 1:40,000.

1983, The Hurricane Mountain Formation melange and unconformably overlying Lower to Middle Ordovician volcanics, Brassua Lake and Moosehead Lake quadrangles, in New England Intercollegiate Geological Conference, 75th Annual Meeting, Greenville, Maine, Oct. 7-9, 1983, Guidebook for field trips in the Greenville-Millinocket regions, north-central Maine: p. 31-44. (Edited by D.W. Caldwell and L.S. Hanson) 1985, Bedrock geologic map of the Pierce Pond, Maine, 
15-minute quadrangle: Maine Geological Survey Open-File Map 85-86, scale 1:62,500.

Boone, G.M., and Boudette, E.L., 1989, Accretion of the Boundary Mountains terrane within the northern Appalchian orthotectonic zone, in Horton, J.W., Jr., and Rast, Nicholas, eds., Melanges and olistostromes of the U.S. Appalachians: Geological Society of America Special Paper 228, p. 17-42.

Boone, G.M., Boudette, E.L., and Moench, R.H., 1970, Bedrock geology of the Rangeley Lakes-Dead River basin region, western Maine, in New England Intercollegiate Geological Conference, 62d Annual Meeting, Rangeley, Me., Oct. 2-4, 1970, Guidebook for trips in the Rangeley Lakes-Dead River basin region, western Maine: [Syracuse, N.Y., Syracuse University, Department of Geology], p. 1-24. (Edited by G.M. Boone.)

Boucot, A.J., 1961, Stratigraphy of the Moose River synclinorium, Maine: U.S. Geological Survey Bulletin 1111-E, p. 153-188.

1969, Geology of the Moose River and Roach River synclinoria, northwestern Maine, with contributions by E.W. Heath: Maine Geological Survey Bulletin 21, 117 p.

Boucot, A.J., Griscom, Andrew, and Allingham, J.W., 1964, Geologic and aeromagnetic map of northern Maine: U.S. Geological Survey Geophysical Investigations Map GP-312, scale $1: 250,000$.

Boudette, E.L., 1970, Pre-Silurian rocks in the Boundary Mountains anticlinorium, northwestern Maine, in New England Intercollegiate Geological Conference, 62d Annual Meeting, Rangeley, Me., Oct. 2-4, 1970, Guidebook for trips in the Rangeley Lakes-Dead River basin region, western Maine: [Syracuse, N.Y., Syracuse University, Department of Geology], p. C1-C21. (Edited by G.M. Boone.)

1978, The stratigraphy and structure of the Kennebago Lake quadrangle, west central Maine: Hanover, N.H., Dartmouth College, unpublished Ph.D. thesis, $346 \mathrm{p}$.

1982, Ophiolite assemblage of early Paleozoic age in central western Maine, in St-Julien, Pierre, and Béland, J., ed., Major structural zones and faults of the northern Appalachians: Geological Association of Canada Special Paper 24, p. 209-230.

Boudette, E.L., and Boone, G.M., 1971, Pre-Silurian stratigraphic succession in west-central Maine [abs.]: Geological Society of America, Abstracts with Programs, v. 3, no. 1, p. 19-20.

-1976, Pre-Silurian stratigraphic succession in central western Maine, in Page, L.R., ed., Contributions to the stratigraphy of New England: Geological Society of America Memoir 148, p. 79-96.

1982, Diamictite of the Chain Lakes Massif of Maine; a possible metasuevite? [abs.]: Geological Society of America, Abstracts with Programs, v. 14, no. 7, p. 448.

1984, Major boundaries in the geologic framework of western Maine: Geological Society of America, Abstracts with Programs, v. 16, no. 1, p. 5.

Boynton, G.R., and Gilbert, F.P., 1964a, Aeromagnetic map of the Cupsuptic quadrangle, Oxford and Franklin Counties, Maine: U.S. Geological Survey Geophysical Investigations Map GP-477, scale $1: 62,500$.

1964b, Aeromagnetic map of the Oquossoc quadrangle, Oxford and Franklin Counties, Maine: U.S. Geological Survey Geophysical Investigations Map GP-478, scale 1:62,500.

1964c, Aeromagnetic map of the Phillips quadrangle, Franklin County, Maine: U.S. Geological Survey Geophysical Investigations Map GP-479, 1:62,500. -1964d, Aeromagnetic map of the Rangeley quadrangle and part of the Kennebago Lake quadrangle, Franklin and Oxford Counties, Maine: U.S. Geological Survey Geophysical Investigations Map GP-480, scale 1:62,500.

Bromery, R.W., and Gilbert, F.P., 1962, Aeromagnetic map of the Skinner and parts of the Attean and Sandy Bay quadrangles, Somerset and Franklin Counties, Maine: U.S. Geological Survey Geophysical Investigations Map GP-310, scale $1: 62,500$.

Bromery, R.W., Soday, Harry, and others, 1963, Aeromagnetic map of the Spencer Lake quadrangle, Franklin and Somerset Counties, Maine: U.S. Geological Survey Geophysical Investigations Map GP-331, scale 1:62,500.

Bromery, R.W., Tyson, N.S., and others, 1963, Aeromagnetic map of the Stratton quadrangle, Franklin and Somerset Counties, Maine: U.S. Geological Survey Geophysical Investigations Map GP-333, scale 1:62,500.

Burroughs, W.A., 1979, Preliminary bedrock geology of the Spencer Lake 15-minute quadrangle, Maine: Maine Geological Survey, Open-File Report 79-1, 12 p., scale 1:62,500.

Cady, W.M., 1960, Stratigraphic and geotectonic relationships in northern Vermont and southern Quebec: Geological Society of America Bulletin, v. 71, no. 5, p. 531-576.

1967, Geosynclinal setting of the Appalachian Mountains in southeastern Quebec and northwestern New England, in Clark, T.H., ed., Appalachian tectonics: Royal Society of Canada, Special Publication 10, p. 57-68.

Coish, R.A., and Rogers, N.W., 1987, Geochemistry of the Boil Mountain ophiolitic complex, northwest Maine, and tectonic implications: Contributions to Mineralogy and Petrology, v. 97, p. $51-65$.

Dale, T.N., 1907, The granites of Maine: U.S. Geological Survey Bulletin 313, $202 \mathrm{p}$.

Eisenberg, R.A., 1981, Chronostratigraphy of metavolcanic and associated intrusive rocks of the Boundary Mountains anticlinorium [abs.]: Geological Society of America, Abstracts with Programs, v. 13, no. 3, p. 131.

Ells, R.W., 1887, Report on the geology of a portion of the eastern townships of Quebec, relating more especially to the counties of Compton, Stanstead, Beauce, Richmond, and Wolfe: Canada Geological Survey Annual Report 2, part J, 70 p.

Espenshade, G.H. and Boudette, E.L., 1967, Geology and petrology of the Greenville quadrangle, Piscataquis and Somerset Counties, Maine: U.S. Geological Survey Bulletin 1241-F, p. F1-F60.

Green, J.C., 1964, Stratigraphy and structure of the Boundary Mountain anticlinorium in the Errol quadrangle, New Hampshire-Maine: Geological Society of America Special Paper 77, $78 \mathrm{p}$.

1968, Geology of the Connecticut Lakes-Parmachenee area, New Hampshire and maine: Geological Society of America Bulletin, v. 79, no. 11, p. 1601-1638.

Green, J.C., and Guidotti, Charles, 1968, Geology of the Boundary Mountain anticlinorium in northern New Hampshire and northwestern Maine, chapter 19, in Zen, E-an, and others, eds., Studies of Appalachian geology, northern and maritime: New York, Interscience Publishers, p. 225-226.

Guidotti, C.V., 1977, The geology of the Oquossoc 15-minute quadrangle, west central Maine: Maine Geological Survey, Open-File Report 77-2, $26 \mathrm{p}$.

Harwood, D.S., 1973, Bedrock geology of the Cupsuptic and Arnold Pond quadrangles, west-central Maine: U.S. Geolog- 
ical Survey Bulletin 1346, 90 p.

Harwood, D.S., and Berry, W.B.N., 1967, Fossiliferous lower Paleozoic rocks in the Cupsuptic quadrangle, west-central Maine, in Geological Survey Research 1967: U.S. Geological Survey Professional Paper 575-D, p. D16-D23.

Harwood, D.S., Green, J.C., and Guidotti, C.V., 1970, Geology of the lower Paleozoic rocks in the Boundary Mountain anticlinorium, in New England Intercollegiate Geological Conference, 62d Annual Meeting, Rangeley, Me., Oct. 2-4, 1970, Guidebook for trips in the Rangeley Lakes-Dead River basin region, western Maine: [Syracuse, N.Y., Syracuse University, Department of Geology], Trip A-3, p. 1-19. (edited by G.M. Boone.)

Henderson, J.R., Gilbert, F.P., and others, 1963a, Aeromagnetic map of the Chain Lakes quadrangle, Franklin and Somerset Counties, Maine: U.S. Geological Survey Geophysical Investigations Map GP-330, scale 1:62,500.

1963b, Aeromagnetic map of the Kennebago Lake quadrangle, Franklin County, Maine: U.S. Geological Survey Geophysical Investigations Map GP-332, scale 1:62,500.

Henderson, J.R., and Smith, C.W., 1964, Aeromagnetic map of the Old Speck Mountain quadrangle, Franklin and Oxford Counties, Maine: U.S. Geological Survey Geophysical Investigations Map GP-486, scale 1:62,500.

Hitchcock, C.H., 1877, The geology of New Hampshire, part II, Stratigraphical geology: Concord, N.H., [publisher unknown], 684 p.

1878, Atlas accompanying the report on the geology of New Hampshire: New York, [publisher unknown].

Hitchcock, C.H., and Huntington, J.H., 1874, Geology of the northwestern part of Maine: American Association for the Advancement of Science, Proceedings 22, pt. 2, p. 205-214.

Holmes, Ezekiel, and Hitchcock, C.H., 1861, Preliminary report upon the natural history and geology of the State of Maine, 1861: Maine Board of Agriculture, 6th annual report, $p$. $91-458$.

1862, Second annual report upon the natural history and geology of the State of Maine, 1862: Maine Board of Agriculture, 7th annual report, p. 217-447.

Hussey, A.M., II, Chapman, C.A., Doyle, R.G., Osberg, P.H., Pavlides, Louis, and Warner, Jeffrey, compilers, 1967, Preliminary geologic map of Maine: Augusta, Me., Maine Geological Survey, scale 1:500,000.

Jackson, C.T., 1837, First report on the geology of the State of Maine: Augusta, Me., [publisher unknown], $128 \mathrm{p}$.

1839, Third annual report on the geology of the State of Maine: Augusta, Me., [publisher unknown], $276 \mathrm{p}$.

Kane, M.F., and Bromery, R.W., 1966, Simple Bouguer gravity map of Maine: U.S. Geological Survey Geophysical Investigations Map GP-580, scale 1:500,000.

1968, Gravity anomalies in Maine, chapter 31 in Zen, E-an, and others, eds., Studies of Appalachian geology, northern and maritime: New York, Interscience Publishers, p. 415-423.

Kane, M.F., and Peterson, D.L., 1961, Preliminary interpretation of gravity data in west-central Maine: U.S. Geological Survey Open-File Report, 10 p., scale 1:250,000.

Keith, Arthur, 1933, Preliminary geologic map of Maine: Maine Geological Survey, Supplement to Maine Technology Experiment Station Bulletin 30, v. 2, scale 1:1,000,000.

Lyons, J.B., Aleinikoff, J.N., and Zartman, R.E., 1983, U-Pb ages of zircons from the Ordovician Highlandcroft plutonic suite and Silurian intrusives [abs.]: Geological Society of America, Abstracts with Programs, v. 15 , no. 3, p. 187

Lyons, J.B., Boudette, E.L., and Aleinikoff, J.N., 1982, The Avalonian and Gander zones in central eastern New England, in St-Julien, Pierre, and Béland, J., eds., Major structural zones and faults of the northern Appalachians: Geological Association of Canada Special Paper 24, p. 43-66.

Marleau, R.A., 1957, Preliminary report on Woburn area, electoral district of Frontenac: Quebec Department of Mines, Geological Surveys Branch Preliminary Report 336, 6 p.

1958, Geology of the Woburn, East Megantic, and Armstrong area, Frontenac and Beauce counties, Quebec: Quebec, Laval University, unpublished Ph.D. thesis, 184 p.

-1968, Woburn-East Megantic-Armstrong area, Frontenac and Beauce Counties: Quebec Department of Natural Resources Geological Report 131, 55 p.

Moench, R.H., 1966, Relation of S2 schistosity to metamorphosed clastic dikes, Rangeley-Phillips area, Maine: Geological Society of America Bulletin, v. 77, no. 12, p. 1449-1461.

1969, The Quimby and Greenvale Cove Formations in western Maine: U.S. Geological Survey Bulletin 1274-L, $17 \mathrm{p}$.

1970a, Premetamorphic down-to-basin faulting, folding, and tectonic dewatering, Rangeley area, western Maine: Geological Society of America Bulletin, v. 81, no. 5, p. 1463-1496.

$1970 \mathrm{~b}$, Evidence for premetamorphic faulting in the Rangeley quadrangle, western Maine, in New England Intercollegiate Geological Conference, 62d Annual Meeting, Rangeley, Me., Oct. 2-4, 1970, Guidebook for trips in the Rangeley Lakes-Dead River basin region, western Maine: [Syracuse, N.Y., Syracuse University, Department of Geology], Trip D, p. 1-12. (edited by G.M. Boone.)

1971, Geologic map of the Rangeley and Phillips quadrangles, Franklin and Oxford Counties, Maine: U.S. Geological Survey Miscellaneous Geologic Investigations Map I-605, scale 1:62,500.

1973, Down-basin fault-fold tectonics in western Maine, with comparisons to the Taconic klippen, in De Jong, K.E., and Scholten, Robert, eds., Gravity tectonics: New York, John Wiley and Sons, p. 327-342.

1984, Geologic map of the Sherbrooke-Lewiston area, Maine, New Hampshire, and Vermont: U.S. Geological Survey Open-File Report 84-650, scale 1:250,000.

Moench, R.H., and Boudette, E.L., 1970, Stratigraphy of the northwest limb of the Merrimack synclinorium in the Kennebago Lake, Rangeley, and Phillips quadrangles, western Maine, in New England Intercollegiate Geological Conference, 62d Annual Meeting, Rangeley, Me., Oct. 2-4, 1970, Guidebook for trips in the Rangeley Lakes-Dead River basin region, western Maine: [Syracuse, N.Y., Syracuse University, Department of Geology], Trip A-1, p. 1-25. (edited by G.M. Boone.)

1987, Stratigraphy of the Rangeley area, Maine: Boulder, Colo., Geological Society of America Centennial Field Guide -Northeast Section, p. 273-278.

Moench, R.H., Boudette, E.L., and Boone, G.M., 1981, Two stratigraphically separate pre-Silurian volcanic sequences in northern New England-A summary of stratigraphy and problems [abs.]: Geological Society of America, Abstracts with Programs, v. 13 , no. 3, p. 166.

Moench, R.H., and Pankiwskyj, K.A., 1988, Geologic map of 
western interior Maine: U.S. Geological Survey Miscellaneous Investigations Series Map I-1692 scale 1:250,000.

Moench, R.H., St-Julien, Pierre, Boone, G.M., Boudette, E.L., Bothner, W.A., Goldsmith, Richard, Hussey, A.M., II, and Unger, J.D., 1989, Northern Appalachian transect-Southeastern Quebec, Canada, through western Maine, U.S.A.: American Geophysical Union, 28th International Geological Congress, Field Trip Guidebook T358, 52 p.

Moench, R.H., and Zartman, R.E., 1976, Chronology and styles of multiple deformation, plutonism, and polymetamorphism in the Merrimack Synclinorium of western Maine, in Lyons, P.C., and Brownlow, A.H., eds., Studies in New England geology; northern New England: Geological Society of America Memoir 146, p. 203-238.

Naylor, R.S., 1975, Age provinces in the northern Appalachians: Annual Review of Earth and Planetary Science, v. 3, p. $387-400$.

Naylor, R.S., Boone, G.M., Boudette, E.L., Ashenden, D.O., and Robinson, Peter, 1973, Pre-Ordovician rocks in the Bronson Hill and Boundary Mountains anticlinoria, New England, U.S.A. [abs.]: EOS (Transactions, American Geophysical Union), v. 54, no. 4, p. 495.

Neuman, R.B., 1968, Paleogeographic implications of Ordovician shelly fossils in the Magog belt of the northern Appalachian region, chapter 3 in Zen, E-an, and others, eds., Studies of Appalachian geology, northern and maritime: New York, Interscience Publishers, p. 35-48.

Osberg, P.H., Hussey, A.M., II, and Boone, G.M., (eds.), 1985, Bedrock geologic map of Maine: Augusta, Me., Maine Geological Survey, scale 1:500,000.

Osberg, P.H., Moench, R.H., and Warner, Jeffrey, 1968, Stratigraphy of the Merrimack synclinorium in west-central Maine, chapter 18 in Zen, E-an, and others, eds., Studies of Appalachian geology, northern and maritime: New York, Interscience Publishers, p. 241 in 253.

Pankiwskyj, K.A., 1970, Geology of Limestone Hill, Stratton Quadrangle, Somerset County, Maine, in Shorter contributions to Maine geology: Maine Geological Survey Bulletin 23, p. 19-26.

Pettijohn, F.J., and Potter, P.E., 1964, Atlas and glossary of primary sedimentary structures: New York, Springer-Verlag, Inc., $370 \mathrm{p}$.

Poole, W.H., 1967, Tectonic evolution of the Appalachian region of Canada, in Neale, E.R.W., and Williams, Harold, eds.,
Collected papers on geology of the Atlantic region-Hugh Lilly memorial volume: Geological Association of Canada Special Paper 4, p. 9-51.

Post, E.V., and Hite, J.B., 1964, Heavy metals in stream sediment, west-central Maine: U.S. Geological Survey Mineral Investigations Field Studies Map MF-278, scale 1:250,000.

Pratt, E.S., and Allen, H.W., 1949, A reconnaissance survey of limestones in Franklin County, Maine: Orono, Me., Maine State Geologist Report, 1947-1948, p. 23-29.

Serra, Sandro, 1973, Structure and stratigraphy of pre-Silurian rocks in west central Somerset County: Syracuse, N.Y., Syracuse University, unpulished M.S. thesis, 104 p.

Smith, E.S.C., 1923, The Rangeley conglomerate [Maine]: American Journal of Science, 5th series, v. 5, p. 147-154.

U.S. Geological Survey, 1961, Regional geologic mapping in Maine, in Geological Survey Research 1961: U.S. Geological Survey Professional Paper 424-A, p. 12.

1965, Fossils indicate margin onlap during Llandovery to Ludlow time, in U.S. Geological Survey Research 1965: U.S. Geological Survey Professional Paper 525-A, p. 74.

Vehrs, T.I., 1975, Tectonic, petrologic, and stratigraphic analysis of the Bigelow Range, Stratton and Little Bigelow Mountain quadrangles, northwestern Maine: Syracuse, N.Y., Syracuse University, unpublished Ph.D. thesis, $196 \mathrm{p}$.

Willard, R.J., 1958, The geology of the Kennebago Lake quadrangle: Boston, Mass., Boston University, unpublished Ph.D. thesis, $338 \mathrm{p}$.

1959a, The geology of the Kennebago Lake quadrangle [Maine] [abs.]: Dissertation Abstracts, v. 19, no. 11, p. 2917-2918.

1959b, Interpretation of fracture patterns in the Kennebago Lake quadrangle, Maine: Arkansas Academy of Science Proceedings, v. 13, p. 91-102.

Williams, Harold, compiler, 1978, Tectonic lithofacies map of the Appalachian orogen: St. John, Newfoundland, Memorial University of Newfoundland, scale 1:1,000,000.

Wing, L.A., 1951a, Asbestos and serpentine rocks of Maine: Orono, Me., Maine Geological Survey, Report of the State Geologist, 1949-50, p. 35-46.

1951b, Summary report on Maine greenstones: Orono, Me., Maine Geological Survey, Report of the State Geologist, 1949-50, p. 47-60.

Wing, L.A., and Dawson, A.S., 1949, Preliminary report on asbestos and associated rocks of northwestern Maine: Orono, Me., Maine State Geologist Report 1947-1948, p. 30-62. 